\title{
Managing multiple myeloma
}

\author{
Ann S. Lee MD MEd, Roger Y. Tsang MD, Irwindeep Sandhu MD
}

Cite as: CMAJ 2021 August 30;193:E1349. doi: 10.1503/cmaj.202824

\section{Multiple myeloma is the second most common malignant \\ 1 hematologic disease in Canada}

The incidence of multiple myeloma in Canada is 55 per 1000000 people, and the prevalence is increasing. ${ }^{1}$ Novel therapies, such as immunomodulatory drugs and proteasome inhibitors, have increased progression-free 5-year survival from $29 \%$ in 1997 to $68 \%$ in 2014 among patients who have received autologous stem cell transplantation. ${ }^{2}$

2

All patients with multiple myeloma should be referred early for assessment of transplant eligibility

Eligibility for therapy, including autologous stem cell transplant, is determined not only by age and renal function, but also by comorbidities and functional status. ${ }^{3}$ All-cause mortality rates 100 days post-transplantation are similar for younger (40-60 yr) compared with older $(\geq 60 \mathrm{yr}$ ) patients ( $1 \% \mathrm{v} .2 \%){ }^{3}$

\section{3}

\section{Bisphosphonates are recommended for all patients with} multiple myeloma, regardless of evidence of bone disease Zoledronic acid and pamidronate prevent osteopenia, lytic disease and fractures. Dosing and frequency depend on indications and risk factors. ${ }^{4}$ Use of more potent intravenous bisphosphonates, however, increases the risk of osteonecrosis of the jaw; regular dental assessments can reduce associated risks.

Prophylactic antibiotics, immunoglobulin replacement and inactivated vaccines may mitigate infections

Disease- and treatment-related factors confer a 10 -fold and sevenfold increased risk of viral and bacterial infections, respectively, for patients with multiple myeloma. ${ }^{5}$ Prophylactic fluoroquinolone is often prescribed by the specialist team within the first 3 months of diagnosis for patients beginning active treatment. ${ }^{5}$ In patients with frequent or severe infections, immunoglobulin replacement, with or without long-term antibiotics, may be considered. Inactivated influenza and pneumococcal polysaccharide vaccines should be administered to all patients.

5 Clinicans should have a low threshold for performing skin biopsies of new lesions with concerning features Patients with multiple myeloma have an increased risk of skin cancer, independent of age and ethnicity. ${ }^{6}$ In particular, the rate of squamous cell carcinoma is 2.4 times higher than for age-matched controls. ${ }^{6}$

\section{References}

1. Tsang M, Le M, Ghazawi FM, et al. Multiple myeloma epidemiology and patient geographic distribution in Canada: a population study. Cancer 2019;125:2435-44.

2. Nishimura KK, Barlogie B, van Rhee F, et al. Long-term outcomes after autologous stem cell transplantation for multiple myeloma. Blood Adv 2020;4:422-31.

3. Mikhael J, Ismaila N, Cheung MC, et al. Treatment of multiple myeloma: ASCO and CCO joint clinical practice guideline. [published erratum in: J Clin Oncol 2020;38:2469]. J Clin Oncol 2019;37: 1228-63.

4. Anderson K, Ismaila N, Flynn PJ, et al. Role of bone-modifying agents in multiple myeloma: American Society of Clinical Oncology clinical practice guideline update. J Clin Oncol 2018;36:812-8.

5. Blimark C, Holmberg E, Mellqvist UH, et al. Multiple myeloma and infections: a population-based study on 9253 multiple myeloma patients. Haematologica 2015;100:107-13.

6. Robinson AA, Wang J, Vardanyan S, et al. Risk of skin cancer in multiple myeloma patients: a retrospective cohort study. Eur $J$ Haematol 2016;97:439-44.

Competing interests: Irwindeep Sandhu reports speaker fees from, and board participation with, Celgene/BMS, Amgen, Gilead/Kite, Janssen, Takeda, Beigene, Novartis and Pfizer, as well as stock with IllumiSonics Inc. No other competing interests were declared.

This article has been peer reviewed.

Affiliations: Department of Family Medicine (Lee), University of Alberta, Edmonton, Alta.; Department of Oncology (Tsang), University of Calgary, Tom Baker Cancer Centre, Calgary, Alta.; Department of Medical Oncology (Sandhu), University of Alberta, Cross Cancer Institute, Edmonton, Alta.

Content licence: This is an Open Access article distributed in accordance with the terms of the Creative Commons Attribution (CC BY-NC-ND 4.0) licence, which permits use, distribution and reproduction in any medium, provided that the original publication is properly cited, the use is noncommercial (i.e., research or educational use), and no modifications or adaptations are made. See: https://creativecommons.org/licenses/by-nc-nd/4.0/

Acknowledgements: The authors would like to acknowledge Dr. Michelle Morros and Dr. Alison White for feedback on earlier versions of this manuscript.

Correspondence to: Ann Lee, ann.lee@ualberta.ca 